\title{
Maternal Thyroid Hormones and Ageing Process
}

\author{
Ahmed R.G. \\ Division of Anatomy and Embryology, Zoology Department, Faculty of Science, Beni-Suef University, Beni- \\ Suef, Egypt
}

*Corresponding Author: Ahmed R.G., Division of Anatomy and Embryology, Zoology Department, Faculty of Science, Beni-Suef University, Beni-Suef, Egypt

\section{SHORT COMMUNICATION}

The regular levels of maternal thyroid hormones (THs) during the gestation show a fundamental action in the developing brain of fetuses, neonates (El-bakry et al., 2010; Ahmed, 2011, 2012a,b, 2013, 2014, 2015a-c, 2016a-d, 2017a-v, 2018a-r; Ahmed and Ahmed, 2012; Ahmed et al., 2008; 2010; 2012; 2013a,b, 2014, 2015a,b, 2018a,b; Ahmed and Incerpi, 2013; Van Herck et al., 2013; Ahmed and El-Gareib, 2014, Incerpi et al., 2014; Candelotti et al., 2015; De Vito et al., 2015; ElGhareeb et al., 2016; Ahmed and El-Gareib, 2017), youth, and adult (Hollowell et al., 2002; Gussekloo et al., 2004; Razvi et al., 2008; Cooper and Biondi, 2012; Gesing et al., 2012; Aggarwal and Razvi, 2013; Gesing, 2015; Pasqualetti et al., 2016).

On the other hand, the prevalence of subclinical hypothyroidism [the levels of free thyroxine (FT4) and free triiodothyronine (FT3) is normal but the level of thyroid-stimulating hormone (TSH) is increased)] is more frequently in the elderly than in the neonates (Gesing, 2015). These disturbances can increase the risk of longevity (Cooper and Biondi, 2012; Kahapola-Arachchige et al., 2012; Gesing, 2015; Hennessey et al., 2015). In patients <65 years, there are direct associations between the subclinical hypothyroidism and cardiovascular disorders (both ischemic heart disease and stroke) (Rodondi et al., 2010; Pasqualetti et al., 2013 \& 2016). In mild thyroid dysfunctions with the ageing process, several neurological diseases such as cognitive defects and dementia can be developed and progressed (Kaddurah-daouk et al., 2010; Ge et al., 2012; Tognini et al., 2014; Pasqualetti et al., 2015). More importantly, data from several animal models proposed that a strong adverse link between the level of THs and lifespan/longevity (Buffenstein et al., 2001; Bowers et al., 2013). The distortion in the levels of THs in the brain (basal forebrain cholinergic neurons) due to some modifications in the activities of deiodinases could cause Alzheimer disease (AD; abnormal deposition or aggregations of beta-amyloid precursor protein (APP) in the brain) (Mafrica and Fodale, 2008). This might be related to the clinical appearance of dementia (Davis et al., 2004). On the other hand, in mice brain and neuronal cell lines, the treatment by T3 can inhibit the expression of APP gene at promoter region (histone $\mathrm{H} 3$ acetylation and methylation) (Belakavadi et al., 2011).

Based on the above evidences, the equilibrium in the maternal hypothalamus-pituitary-thyroid axis (HPTA) shows significant roles during the development and adulthood periods. The previous observations raise the possibility that the frequency of thyroid disorders may upsurge with age. In addition, the dysregulations in the maternal THs may delay the development of neural connections, and neurobehavioral responses. These sustained problems may confirm the presence of ageing disorders in the future. However, these alterations may depend on the nature of population, sex, age, nutrition, and ethnicity. Thus, serum T4, T3 and TSH testing should be done in both mothers and their neonates during the early suckling period so that any thyroid dysfunctions can be identified early and treated to avoid the ageing disorders in adult. In addition, supplementary studies are desired to identify whether the problems of maternal thyroid dysfunctions may increase the risk of persistent conflicts and ageing defects. These arguments require more examinations and special attentions in elderly persons. 


\section{REFERENCES}

Aggarwal, N., Razvi, S., 2013. Thyroid and aging or the aging thyroid? an evidence-based analysis of the literature. Journal of Thyroid Research 1-8.

Ahmed, O.M., Abd El-Tawab, S.M., Ahmed, R.G., 2010. Effects of experimentally induced maternal hypothyroidism and hyperthyroidism on the development of rat offspring: I- The development of the thyroid hormones-neurotransmitters and adenosinergic system interactions. Int. J. Dev. Neurosci. 28, 437454.

Ahmed, O.M., Ahmed, R.G., 2012. Hypothyroidism. In A New Look At Hypothyroidism. Dr. D. Springer (Ed.), ISBN: 978-953-51-0020-1), In Tech Open Access Publisher, Chapter 1, pp. 1-20.

Ahmed, O.M., Ahmed, R.G., El-Gareib, A.W., El-Bakry, A.M., Abd El-Tawaba, S.M., 2012. Effects of experimentally induced maternal hypothyroidism and hyperthyroidism on the development of rat offspring: II-The developmental pattern of neurons in relation to oxidative stress and antioxidant defense system. Int. J. Dev. Neurosci. 30, 517-537.

Ahmed, O.M., El-Gareib, A.W., El-bakry, A.M., Abd El-Tawab, S.M., Ahmed, R.G., 2008. Thyroid hormones states and brain development interactions. Int. J. Dev. Neurosci. 26(2), 147-209. Review.

Ahmed, R.G., 2011. Perinatal 2, 3, 7, 8-tetrachlorodibenzo-p-dioxin exposure alters developmental neuroendocrine system. Food Chem. Toxicology, 49, 1276-1284.

Ahmed, R.G., 2012a. Maternal-newborn thyroid dysfunction. In the Developmental Neuroendocrinology, pp. 1369. Ed R.G. Ahmed. Germany: LAP LAMBERT Academic Publishing GmbH \& Co KG.

Ahmed, R.G., 2012b. Maternal-fetal thyroid interactions, Thyroid Hormone, Dr. N.K. Agrawal (Ed.), ISBN: 978-953-51-0678-4, In Tech Open Access Publisher, Chapter 5, pp. 125-156.

Ahmed, R.G., 2013. Early weaning PCB 95 exposure alters the neonatal endocrine system: thyroid adipokine dysfunction. J. Endocrinol. 219 (3), 205-215.

Ahmed, R.G., 2014. Editorial: Do PCBs modify the thyroid-adipokine axis during development? Annals Thyroid Res. 1(1), 11-12.

Ahmed, R.G., 2015a. Chapter 1: Hypothyroidism and brain development. In advances in hypothyroidism treatment. Avid Science Borsigstr. 9, 10115 Berlin, Berlin, Germany. Avid Science Publications level 6, Melange Towers, Wing a, Hitec City, Hyderabad, Telangana, India. pp. 1-40.

Ahmed, R.G., 2015b. Hypothyroidism and brain developmental players. Thyroid Research J. 8(2), 1-12.

Ahmed, R.G., 2015c. Editorials and Commentary: Maternofetal thyroid action and brain development. J. of Advances in Biology; 7(1), 1207-1213.

Ahmed, R.G., 2016a. Gestational dexamethasone alters fetal neuroendocrine axis. Toxicology Letters, 258, 4654.

Ahmed, R.G., 2016b. Neonatal polychlorinated biphenyls-induced endocrine dysfunction. Ann. Thyroid. Res. 2 (1), 34-35.

Ahmed, R.G., 2016c. Maternal iodine deficiency and brain disorders. Endocrinol. Metab. Syndr. 5, 223. http://dx.doi.org/10.4172/2161-1017.1000223.

Ahmed, R.G., 2016d. Maternal bisphenol A alters fetal endocrine system: Thyroid adipokine dysfunction. Food Chem. Toxicology, 95, 168-174.

Ahmed, R.G., 2017a. Developmental thyroid diseases and GABAergic dysfunction. EC Neurology 8.1, 02-04.

Ahmed, R.G., 2017b. Hyperthyroidism and developmental dysfunction. Arch Med. 9, 4.

Ahmed, R.G., 2017c. Anti-thyroid drugs may be at higher risk for perinatal thyroid disease. EC Pharmacology and Toxicology 4.4, 140-142.

Ahmed, R.G., 2017d. Perinatal hypothyroidism and cytoskeleton dysfunction. Endocrinol Metab Syndr 6, 271. doi:10.4172/2161-1017.1000271

Ahmed, R.G., 2017e. Developmental thyroid diseases and monoaminergic dysfunction. Advances in Applied Science Research 8(3), 01-10.

Ahmed, R.G., 2017f. Hypothyroidism and brain development. J. Anim Res Nutr. 2(2), 13.

Ahmed, R.G., 2017g. Antiepileptic drugs and developmental neuroendocrine dysfunction: Every why has A Wherefore. Arch Med 9(6), 2.

Ahmed, R.G., 2017h. Gestational prooxidant-antioxidant imbalance may be at higher risk for postpartum thyroid disease. Endocrinol Metab Syndr 6, 279. doi:10.4172/2161-1017.1000279.

Ahmed, R.G., 2017i. Synergistic actions of thyroid-adipokines axis during development. Endocrinol Metab Syndr 6, 280. doi:10.4172/2161-1017.1000280.

Ahmed, R.G., 2017j. Thyroid-insulin dysfunction during development. International Journal of Research Studies in Zoology 3(4), 73-75. DOI: http://dx.doi.org/10.20431/2454-941X.0304010. 
Ahmed, R.G., 2017k. Developmental thyroid diseases and cholinergic imbalance. International Journal of Research Studies in Zoology 3(4), 70-72. DOI: http://dx.doi.org/10.20431/2454-941X.0304009.

Ahmed, R.G., 20171. Thyroid diseases and developmental adenosinergic imbalance. Int J Clin Endocrinol 1(2), 053-055.

Ahmed, R.G., 2017m. Maternal anticancer drugs and fetal neuroendocrine dysfunction in experimental animals. Endocrinol Metab Syndr 6, 281. doi:10.4172/2161-1017.1000281.

Ahmed, R.G., 2017n. Letter: Gestational dexamethasone may be at higher risk for thyroid disease developing peripartum. Open Journal Of Biomedical \& Life Sciences (Ojbili) 3(2), 01-06.

Ahmed, R.G., 2017o. Deiodinases and developmental hypothyroidism. EC Nutrition 11.5, 183-185.

Ahmed, R.G., 2017p. Maternofetal thyroid hormones and risk of diabetes. Int. J. of Res. Studies in Medical and Health Sciences 2(10), 18-21.

Ahmed, R.G., 2017r. Association between hypothyroidism and renal dysfunctions. International Journal of Research Studies in Medical and Health Sciences 2(11), 1-4.

Ahmed, R.G., 2017s. Maternal hypothyroidism and lung dysfunction. International Journal of Research Studies in Medical and Health Sciences 2(11), 8-11.

Ahmed, R.G., 2017t. Endocrine disruptors; possible mechanisms for inducing developmental disorders. International journal of basic science in medicine (IJBSM) 2(4), 157-160.

Ahmed, R.G., 2017u. Maternal thyroid hormones trajectories and neonatal behavioral disorders. ARC Journal of Diabetes and Endocrinology 3(2), 18-21.

Ahmed, R.G., 2017v. Maternal thyroid dysfunction and neonatal cardiac disorders. Insights Biol Med. 1, 092096.

Ahmed, R.G., 2018a. Maternal hypothyroidism and neonatal testicular dysfunction. International Journal of Research Studies in Medical and Health Sciences 3(1), 8-12.

Ahmed, R.G., 2018b. Maternal hypothyroidism and neonatal depression: Current perspective. International Journal of Research Studies in Zoology 4(1), 6-10. DOI: http://dx.doi.org/10.20431/2454-941X.0401002.

Ahmed, R.G., 2018c. Non-genomic actions of thyroid hormones during development. App Clin Pharmacol Toxicol: ACPT-108. DOI: 10.29011/ACPT-109. 100008.

Ahmed, R.G., 2018d. Maternal thyroid function and placental hemodynamics. ARC Journal of Animal and Veterinary Sciences 4(1), 9-13. DOI: http://dx.doi.org/10.20431/2455-2518.0401002.

Ahmed, R.G., 2018e. Interactions between thyroid and growth factors during development. ARC Journal of Diabetes and Endocrinology 4(1), 1-4. DOI: http://dx.doi.org/10.20431/2455-5983.0401001.

Ahmed, R.G., 2018f. Maternal thyroid hormones and neonatal appetite. ARC Journal of Nutrition and Growth 4(1), 18-22. DOI: http://dx.doi.org/10.20431/2455-2550.0401005.

Ahmed, R.G., 2018g. Genomic actions of thyroid hormones during development. ARC Journal of Diabetes and Endocrinology 4(1), 5-8. DOI: http://dx.doi.org/10.20431/2455-5983.0401002.

Ahmed, R.G., 2018h. Dysfunction of maternal thyroid hormones and psychiatric symptoms. American Research Journal of Endocrinology. 2(1), 1-6.

Ahmed, R.G., 2018i. Is there a connection between maternal hypothyroidism and developing autism spectrum disorders? ARC Journal of Neuroscience 3(1), 5-8. DOI: http://dx.doi.org/10.20431/2456-057X.0301002.

Ahmed, R.G., 2018j. Maternal thyroid dysfunctions and neonatal bone maldevelopment. American Research Journal of Endocrinology (in press) Xx-Xxx.

Ahmed, R.G., 2018k. Maternal thyroid disorders and risk of neonatal seizure: Current perspective. ARC Journal of Neuroscience 3(1), 21-25. DOI: http://dx.doi.org/10.20431/2456-057X.0301004

Ahmed, R.G., 20181. Gestational dioxin acts as developing neuroendocrine-disruptor. EC Pharmacology and Toxicology 6.3, 96-100.

Ahmed, R.G., 2018m. Maternal thyroid dysfunction and risk of neonatal stroke. ARC Journal of Animal and Veterinary Sciences 4(1), 22-26. DOI: http://dx.doi.org/10.20431/2455-2518.0401004

Ahmed, R.G., 2018n. Maternal thyroid disorders and developing skin dysfunctions. ARC Journal of Dermatology 3(1), 13-17. DOI: http://dx.doi.org/10.20431/2456-0022.0301005

Ahmed, R.G., 2018o. Maternal hypothyroidism-milk ejections: What is the link? ARC Journal of Nutrition and Growth 4(1), 29-33. DOI: http://dx.doi.org/10.20431/2455-2550.0401007

Ahmed, R.G., 2018p. Does maternal antepartum hypothyroidism cause fetal and neonatal hyponatremia? ARC Journal of Diabetes and Endocrinology 4(1), xx-Xxx. DOI: http://dx.doi.org/10.20431/2455-5983.0401004

Ahmed, R.G., 2018q. Maternal hypothyroidism and rheumatoid arthritis. International Journal of Research Studies in Medical and Health Sciences Volume 3(2), xx-Xxx. 
Ahmed, R.G., 2018r. Developmental thyroid and skeletal muscle dysfunction. ARC Journal of Diabetes and Endocrinology 4(1), xx-xxx. DOI: http://dx.doi.org/10.20431/2455-5983.0401003

Ahmed, R.G., Abdel-Latif, M., Ahmed F., 2015a. Protective effects of GM-CSF in experimental neonatal hypothyroidism. International Immunopharmacology 29, 538-543.

Ahmed, R.G., Abdel-Latif, M., Mahdi, E., El-Nesr, K., 2015b. Immune stimulation improves endocrine and neural fetal outcomes in a model of maternofetal thyrotoxicosis. Int. Immunopharmacol. 29, 714-721.

Ahmed, R.G., Davis, P.J., Davis, F.B., De Vito, P., Farias, R.N., Luly, P., Pedersen, J.Z., Incerpi, S., $2013 a$. Nongenomic actions of thyroid hormones: from basic research to clinical applications. An update. Immunology, Endocrine \& Metabolic Agents in Medicinal Chemistry, 13(1), 46-59.

Ahmed, R.G., El-Gareib, A.W. 2014. Lactating PTU exposure: I- Alters thyroid-neural axis in neonatal cerebellum. Eur. J. of Biol. and Medical Sci. Res. 2(1), 1-16.

Ahmed, R.G., El-Gareib, A.W., 2017. Maternal carbamazepine alters fetal neuroendocrine-cytokines axis. Toxicology 382, 59-66.

Ahmed, R.G., El-Gareib, A.W., Incerpi, S., 2014. Lactating PTU exposure: II- Alters thyroid-axis and prooxidant-antioxidant balance in neonatal cerebellum. Int. Res. J. of Natural Sciences 2(1), 1-20.

Ahmed, R.G., El-Gareib, A.W., Shaker, H.M., 2018a. Gestational 3,3',4,4',5-pentachlorobiphenyl (PCB 126) exposure disrupts fetoplacental unit: Fetal thyroid-cytokines dysfunction. Life Sciences 192, 213-220.

Ahmed, R.G., Incerpi, S., 2013. Gestational doxorubicin alters fetal thyroid-brain axis. Int. J. Devl. Neuroscience 31, 96-104.

Ahmed, R.G., Incerpi, S., Ahmed, F., Gaber, A., 2013b. The developmental and physiological interactions between free radicals and antioxidant: Effect of environmental pollutants. J. of Natural Sci. Res. 3(13), 74110.

Ahmed, R.G., Walaa G.H., Asmaa F.S., 2018b. Suppressive effects of neonatal bisphenol A on the neuroendocrine system. Toxicology and Industrial Health Journal (in press).

Belakavadi, M., Dell, J., Grover, G.J., Fondell, J.D., 2011. Thyroid hormone suppression of $\beta$-amyloid precursor protein gene expression in the brain involves multiple epigenetic regulatory events. Mol Cell Endocrinol $339(1-2), 72-80$.

Bowers, J., Terrien, J., Clerget-Froidevaux, M.S., Gothié, J.D., Rozing, M.P., Westendorp, R.G., 2013. Thyroid hormone signaling and homeostasis during aging. Endocr Rev 34(4), 556-89.

Buffenstein, R., Woodley, R., Thomadakis, C., Daly, T.J., Gray, D.A., 2001. Cold-induced changes in thyroid function in a poikilothermic mammal, the naked mole-rat. Am J Physiol Regul Integr Comp Physiol 280(1), R149-55.

Candelotti, E., De Vito, P., Ahmed, R.G., Luly, P., Davis, P.J., Pedersen, J.Z., Lin, H-Y., Incerpi, I., 2015. Thyroid hormones crosstalk with growth factors: Old facts and new hypotheses. Immun., Endoc. \& Metab. Agents in Med. Chem., 15, 71-85.

Cooper, D.S., Biondi, B., 2012. Subclinical thyroid disease. Lancet 379(9821), 1142-54.

Davis, J.D., Podolanczuk, A., Donahue, J.E., Stopa, E., Hennessey, J.V., Luo, L.G., 2008. Thyroid hormone levels in the prefrontal cortex of post-mortem brains of Alzheimer's disease patients. Curr Aging Sci 1(3), 175-81.

De Vito, P., Candelotti, E., Ahmed, R.G., Luly, P., Davis, P.J., Incerpi, S., Pedersen, J.Z., 2015. Role of thyroid hormones in insulin resistance and diabetes. Immun., Endoc. \& Metab. Agents in Med. Chem., 15, 86-93.

El-bakry, A.M., El-Ghareeb, A.W., Ahmed, R.G., 2010. Comparative study of the effects of experimentallyinduced hypothyroidism and hyperthyroidism in some brain regions in albino rats. Int. J. Dev. Neurosci. 28, 371-389.

El-Ghareeb, A.A., El-Bakry, A.M., Ahmed, R.G., Gaber, A., 2016. Effects of zinc supplementation in neonatal hypothyroidism and cerebellar distortion induced by maternal carbimazole. Asian Journal of Applied Sciences 4(04), 1030-1040.

Ge, J.F., Peng, L., Hu, C.M., Wu, T.N., 2012. Impaired learning and memory performance in a subclinical hypothyroidism rat model induced by hemi-thyroid electrocauterisation. J Neuroendocrinol 24(6), 953-61.

Gesing, A., 2015. The thyroid gland and the process of aging. Thyroid Research 8(Suppl 1), A8.

Gesing, A., Lewiński, A., Karbownik-Lewińska, M., 2012. The thyroid gland and the process of aging; what is new? Thyroid Research 5, 16.

Gussekloo, J., van Exel, E., de Craen, A.J., Meinders, A.E., Frölich, M., Westendorp, R.G., 2004. Thyroid status, disability and cognitive function, and survival in old age. JAMA 292(21), 2591-9.

Hennessey, J.V., Espaillat, R., 2015. Diagnosis and management of subclinical hypothyroidism in elderly adults: A review of the literature. J Am Geriatr Soc 63(8), 1663-73. 
Hollowell, J.G., Staehling, N.W., Flanders, W.D., Hannon, W.H., Gunter, E.W., Spencer, C.A., 2002. Serum TSH, T(4), and hyroid antibodies in the United States population (1988 to 1994): National Health and Nutrition Examination Survey (NHANES III). J Clin Endocrinol Metab 87(2), 489-99.

Incerpi, S., Hsieh, M-T., Lin, H-Y., Cheng, G-Y., De Vito, P., Fiore, A.M., Ahmed, R.G., Salvia, R., Candelotti, E., Leone, S., Luly, P., Pedersen, J.Z., Davis, F.B., Davis, P.J., 2014. Thyroid hormone inhibition in L6 myoblasts of IGF-I-mediated glucose uptake and proliferation: new roles for integrin $\alpha v \beta 3$. Am. J. Physiol. Cell Physiol. 307, C150-C161.

Kaddurah-daouk, R., Clark, J.F. Degrauw, T., 2010. Methods of treating cognitive dysfunction by modulating brain energy metabolism. EP1567180.

Kahapola-Arachchige, K.M., Hadlow, N., Wardrop, R., Lim, E.M., Walsh, J.P., 2012. Age-specific TSH reference ranges have minimal impact on the diagnosis of thyroid dysfunction. Clin Endocrinol (Oxf) 77(5), 773-9.

Mafrica, F., Fodale, V., 2008. Thyroid function, Alzheimer's disease and postoperative cognitive dysfunction: A tale of dangerous liaisons? J Alzheimers Dis 14(1), 95-105.

Pasqualetti, G., Caraccio, N., Dell'Agnello, U., Monzani, F., 2016. Cognitive function and the ageing process: The peculiar role of mild thyroid failure. Recent Patents on Endocrine, Metabolic \& Immune Drug Discovery 10(1), 1-6.

Pasqualetti, G., Pagano, G., Rengo, G., Ferrara, N., Monzani, F., 2015. Subclinical hypothyroidism and cognitive impairment: Systematic review and meta-analysis. J Clin Endocrinol Metab 100(11), 4240-8.

Pasqualetti, G., Tognini, S., Polini, A., Caraccio, N., Monzani, F., 2013. Is subclinical hypothyroidism a cardiovascular risk factor in the elderly? J Clin Endocrinol Metab 98(6), 2256-66.

Razvi, S., Shakoor, A., Vanderpump, M., Weaver, J.U., Pearce, S.H., 2008. The influence of age on the relationship between subclinical hypothyroidism and ischemic heart disease: A metaanalysis. J Clin Endocrinol Metab 93(8), 2998-3007.

Rodondi, N., den Elzen, W.P., Bauer, D.C., Cappola, A.R., Razvi, S., Walsh, J.P., 2010. Subclinical hypothyroidism and the risk of coronary heart disease and mortality. JAMA 304(12), 1365-74.

Tognini, S., Pasqualetti, G., Calsolaro, V., Polini, A., Monzani, F., 2014. Cognitive function and quality of life in mild thyroid hormone deficiency. Recent Pat Endocr Metab Immune Drug Discov 8(2), 124-34.

Van Herck, S.L.J., Geysens, S., Bald, E., Chwatko, G., Delezie, E., Dianati, E., Ahmed, R.G., Darras, V.M., 2013. Maternal transfer of methimazole and effects on thyroid hormone availability in embryonic tissues. Endocrinol. 218, 105-115.

Citation: R. Ahmed, "Maternal Thyroid Hormones and Ageing Process", International Journal of Research Studies in Biosciences (IJRSB), vol. 6, no. 2, pp. 30-34, 2018. http://dx.doi.org/10.20431/2349-0365.0602005

Copyright: (C) 2018 Authors. This is an open-access article distributed under the terms of the Creative Commons Attribution License, which permits unrestricted use, distribution, and reproduction in any medium, provided the original author and source are credited. 